\title{
Phytoplankton diversity and photosynthetic acclimation along a longitudinal transect through a shallow estuary in summer
}

\author{
Arne Schoor ${ }^{1, *}$, Uwe Selig ${ }^{1}$, Ulrike Geiß-Brunschweiger ${ }^{1}$, Ralf Schaible ${ }^{1}$, \\ Rhena Schumann ${ }^{2}$, Bianca Schubert ${ }^{1}$, Peter Feuerpfeil ${ }^{1}$, Martin Hagemann ${ }^{3}$, \\ Hendrik Schubert ${ }^{1}$
}

University of Rostock, ${ }^{1}$ Aquatic Ecology, ${ }^{2}$ Applied Ecology, ${ }^{3}$ Plant Physiology, Albert-Einstein-Str. 3a, 18051 Rostock, Germany

\begin{abstract}
Diversity, nutrients and irradiance acclimation of phytoplankton were investigated along a longitudinal transect through the shallow Darss-Zingst estuary (southern Baltic Sea). Sampling in the pelagial during a stable midsummer clear-sky period served to search for basic longitudinal patterns. Cyanobacteria dominated the phytoplankton biomass. The phytoplankton biomass in the innermost basins decreased with increasing proportions of mesotrophic Baltic Sea water. Individual-based phytoplankton diversity reached maximum values at highly productive sites and was not inversely related to biomass concentration. Marked gradients of dissolved plant nutrients were not observed. Nutrient concentrations and element ratios suggested Redfield limitation by phosphorus. In contrast to element ratios in the particulate pool, dissolved iron concentrations indicated potential iron starvation at several sampling sites. The relatively high concentrations of non-reactive soluble phosphate at many sampling sites made chemical interactions of phosphates and iron probable. The availability of photosynthetically active radiation (PAR) limited the photic zone to a water depth of less than $2 \mathrm{~m}$ in highly productive areas, but a gradual acclimation response of phytoplankton to the longitudinal gradient in irradiance was undetectable. Significant correlations of chl a-normalised carotenoid content and saturation irradiance of photosynthesis $\left(E_{k}\right)$ as well as chl a-normalised carotenoid content and daily incident PAR (sunrise to sampling time) suggest that high photon flux densities (PFDs) in midsummer clear-sky periods prevent effective photosynthetic acclimation of phytoplankton to average low irradiance availability in the turbid water columns. Low variable photosystem II fluorescence after dark incubation indicates inhibitory cross-effects of severe nutrient limitation and stress due to high PFDs at the water surface and/or high oxygen oversaturation in the pelagial. Thus, the photosynthetic machinery may be hampered under certain weather conditions, even in a highly eutrophicated estuary.
\end{abstract}

KEY WORDS: Cyanobacteria $\cdot$ Irradiance $\cdot$ Diversity $\cdot$ Photosynthesis $\cdot$ Phosphorus $\cdot$ Iron $\cdot$ Baltic Sea - Resale or republication not permitted without written consent of the publisher

\section{INTRODUCTION}

Estuaries are characterised by unique horizontal gradients of physical, chemical and biological parameters. The basic salinity gradient is connected to changes in element distribution between the dissolved and particulate phases (e.g. Eyre \& Twigg 1997), trace metal speciation (e.g. Wen et al. 1999) and aggregation behaviour of matter (e.g. Zwolsman et al. 1997), as well as other physical and chemical characteristics like $\mathrm{pH}$, ion distribution and irradiance attenuation. Estuarine sediments represent sources and/or sinks of matter for the pelagial (e.g. Hopkinson et al. 1999) and release dissolved nutrients. Benthic oxygen consumption can determine processes in the pelagial to a large extent (e.g. Boynton \& Kemp 1985). The general impact of the sediment on pelagic processes, however, is primarily defined by hydrological conditions. Hence, the impor- 
tance of sediments and positive feedback of nutrient release is commonly high in shallow or tideless estuaries (e.g. Clavero et al. 2000). Close benthic-pelagic interactions in shallow estuaries can often be detected for the main plant nutrients $(\mathrm{N}, \mathrm{P})$ during the annual season (e.g. Hopkinson et al. 1999). Thus, differently nutrient-enriched sediments can maintain gradients in dissolved nutrients in spite of minor input of allochthonous nutrients.

Although phytoplankton distribution may follow the salinity gradient, disappearance of species and variability in diversity often cannot be sufficiently explained by salinity changes (e.g. Lemaire et al. 2002). Estuarine phytoplankton dynamics at different time scales are influenced by many physical or biological processes, e.g. river runoff, tide, wind-induced mixing, sediment resuspension, irradiance availability and grazing. Of the physical factors, irradiance is of crucial importance for photo-autotrophic organisms. Phytoplankton assemblages adapt themselves to a mean irradiance environment in well-mixed estuaries (e.g. MacIntyre \& Cullen 1996), but acclimation to a given irradiance may also occur in physically stable and homogenous shallow waters at neap tide (Lizon et al. 1995). Under bloom conditions, sophisticated irradiance acclimation mechanisms can be detected in situ (e.g. Schubert et al. 1995). This suggests that a low diversity of higher phytoplankton taxa may facilitate the detection of general acclimation patterns in an entire estuary. In general, the nutrient limitation of phytoplankton growth in estuaries $(\mathrm{N}, \mathrm{P}, \mathrm{Si})$ is seasonal, switching from $\mathrm{N}$ to $\mathrm{P}$, thereby determining succession in estuaries (e.g. Pitkänen \& Tamminen 1995).

The complex dynamic processes in shallow estuaries often hamper investigations on single environmental factors, i.e. their modulation along the longitudinal expansion of the water bodies and their specific role in ecophysiological acclimation. Frequently, general conclusions on the entire system must be derived from investigations at single sites or different sites at divergent times. This often leads to analyses on long-term scales that limit the understanding of diversification in the entire system in a short timeframe. In the case of the Darss-Zingst estuary, midsummer periods provide advantageous preconditions to investigate mechanisms in the longitudinal differentiation of the pelagial due to the reduction in temporal and spatial variability. The latter includes e.g. low frequencies of storm events and irregularly intensive inflows of saline water into the tideless estuary as well as minor spatial differences in sediment resuspension. A stable, clear sky provides long daily insolation periods with minimum spatial variability. The summer season is usually characterised by comparatively slow changes in the phytoplankton composition (Wasmund 1994). These preconditions facilitate investigations into different questions: (1) Do longitudinal gradients of micro- and macronutrients evolve despite the low supply of riverine nutrients in summer? (2) Are these nutrients potentially limiting to phytoplankton development in a highly productive and turbid estuary? (3) Does cyanobacterial dominance in summer lead to detectable irradiance acclimation strategies that can be generalised for total phytoplankton? (4) Does phytoplankton species composition and diversity change along the eutrophication/mixing gradient?

\section{MATERIALS AND METHODS}

Investigation area. The tideless Darss-Zingst estuary (Fig. 1) in the southern Baltic Sea consists of a chain of partially enclosed basins, the so-called 'Bodden', which provide changing hydrological conditions for phytoplankton development. The long-term water exchange is mainly determined by the exchange of water masses with the Baltic Sea and river water inflow (Schlungbaum et al. 1994). Hydrographical and hydrological conditions (Table 1) determine a high productivity level. Besides the typical estuarine salinity gradient, riverine nutrient input leads to gradients of nutrients along the estuary, which include high concentrations of dissolved nutrients, especially in winter and spring (Selig et al. 2006). Massive storage of phosphorus and nitrogen is linked to organically rich sediments (Schlungbaum \& Nausch 1988). Sediments may function as a temporal source of plant nutrients in the pelagial. The small-scale spatial variance of plankton samples is almost negligible at a given sampling site (e.g. Schubert et al. 1997) due to the usually completely mixed water columns (Schubert \& Forster

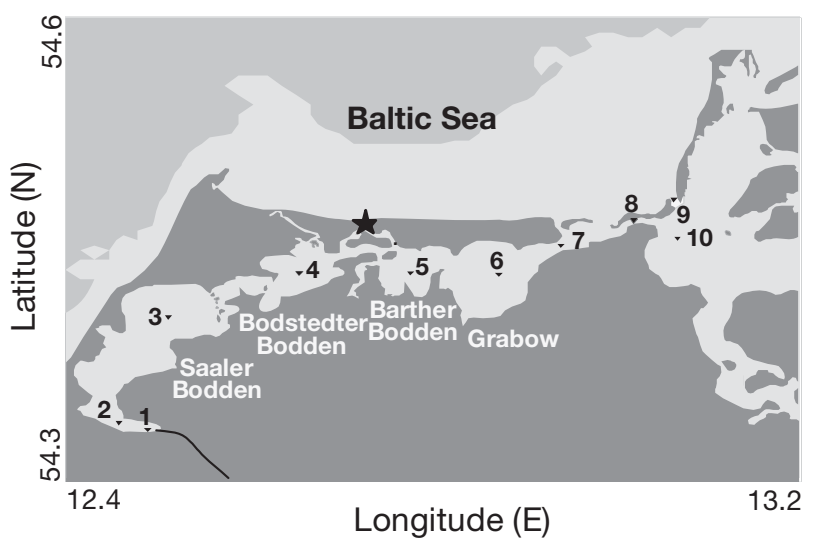

Fig. 1. Sampling sites along the Darss-Zingst estuary. Increasing numbers of sampling sites reflect increasing salinity (see Table 1). The asterisk indicates the Biological Station Zingst, the starting point of both cruises 
Table 1. Hydrography, total variability of salinity and dissolved nutrient gradients during spring (March to April) in the DarssZingst estuary according to long-term data collections. SRP: soluble reactive phosphorus; data from Schlungbaum et al. (1994) and Selig et al. (2005)

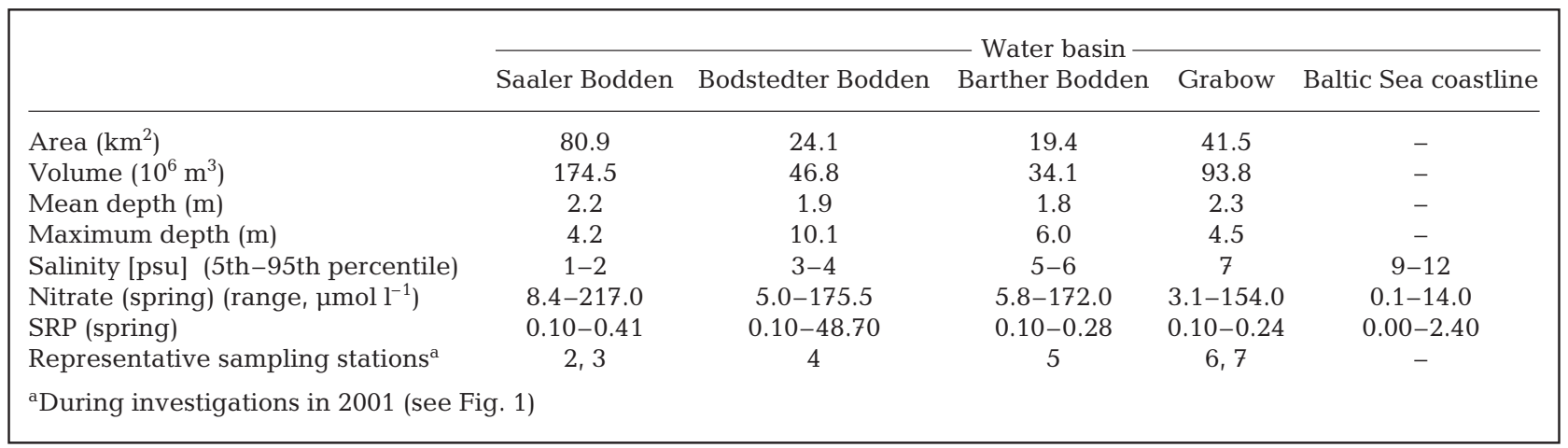

1997). Benthic-pelagic interaction is assumed to be intensive, since the upper sediment layer of the shallow regions becomes re-suspended at wind velocities exceeding the critical limit of $6 \mathrm{~m} \mathrm{~s}^{-1}$ (Nausch \& Schlungbaum 1984). Mucoid and humic materials as well as coloured, dissolved organic matter (cDOM) are of high importance in the pelagic pool of organic matter (Schubert et al. 2001, Görs et al. 2007) and contribute to irradiance attenuation. Chlorophyceae and cyanobacteria dominate the phytoplankton communities (Wasmund 1994, Schumann et al. 2001), which in summer are potentially co-limited by the availability of phosphorus, nitrogen and light (Schiewer 1997).

Sampling scheme. Cruises were made in 2001 to sample the pelagial of the Darss-Zingst estuary along its longitudinal expansion on 23 July (Stns 5 to 10) and 25 July (Stns 1 to 4 ; Fig. 1). Sampling was performed at early noon on the way back to the harbour ( 3 to $5 \mathrm{~h}$ ) to minimise variability owing to sample storage and irradiance exposition of phytoplankton during the day. Samples were taken at the water surface $(0$ to $0.3 \mathrm{~m}$ depth) and stored in polyethylene bottles in darkness until analysis. Laboratory analyses and measurements followed the order of sampling to keep post-sampling periods almost constant for each sample.

Physical and chemical parameters. The water exchange calculations were based on the current salinity at the river mouth (Stn 1) and the long-term mean (1990 to 1999) of salinity values for July (8.75 psu) in coastal waters of the Baltic Sea. The latter included pooled values from 2 stations (O6: $54.376^{\circ} \mathrm{N}, 12.291^{\circ} \mathrm{E}$; O9: $54.621^{\circ} \mathrm{N} 13.024^{\circ} \mathrm{E}$ ) of the Baltic Sea coastline monitored near the Darss-Zingst estuary. These data were provided by the local monitoring administration (Landesamt für Umwelt, Naturschutz und Geologie [LUNG], Mecklenburg-Vorpommern, Germany).

Underwater photosynthetically-active radiation (PAR) was measured with a spherical quantum sensor (SA193) connected to a Li-1000 data logger (both LiCor). Irradi- ance measurements were done underwater at depths of $0.02,0.1,0.2,0.3,0.4,0.5,0.7$ and $1.0 \mathrm{~m}$, followed by $0.5 \mathrm{~m}$ intervals to the sea bottom for the calculation of attenuation coefficients $\left(k_{\mathrm{PAR}}\left[\mathrm{m}^{-1}\right]\right)$. Stations always provided water depths that exceeded the mean water depths of the respective water basins (Table 1). Surface irradiance (ELDONET station) and wind velocity were continuously recorded with the stationary equipment of the Biological Station Zingst in the centre of the westeast expansion of the estuary (Fig. 1).

Dissolved nutrients were analysed after membrane filtration $(0.45 \mu \mathrm{m})$. Ammonium was measured immediately by indophenol blue absorption according to Rohde \& Nehring (1979). Nitrite was determined photometrically as azoic dye after reaction with sulphanilamide (Rohde \& Nehring 1979). Nitrate was reduced to nitrite in the presence of cadmium granules, and the sum of nitrate and nitrite was determined as described for nitrite. The sum of ammonium, nitrite and nitrate was defined as dissolved inorganic nitrogen (DIN). Soluble reactive phosphorus (SRP) was analysed by applying the molybdenum blue method in a flowthrough system according to Malcolme-Lawes \& Koon (1990). After reducing ferric ions in acidified samples, dissolved iron (DFe) was determined as a ferrozine complex (Stookey 1970). For the quantification of dissolved organic carbon (DOC), filtered subsamples (GF/F, Whatman) were analysed with a total organic carbon analyser (TOC 5000 A, Shimadzu), equipped with a suspended particle kit. Absorption scans of dissolved matter were performed with filtered samples (GF/F, Whatman) against deionised, UV-treated water with a double-beam spectrophotometer (Specord M42, Carl Zeiss).

Aliquots of water samples were filtered (GF/F, Whatman) and subsequently dried $\left(60^{\circ} \mathrm{C}, 24 \mathrm{~h}\right)$ to determine particulate matter. Particulate organic carbon (POC) and particulate nitrogen (PN) were analysed with a $\mathrm{C} / \mathrm{N}$ Analyser (Vario EL) according to Verardo et al. 
(1990). Particulate phosphorus (PP) was determined as $\mathrm{HCl}$-soluble residue after heating at $500^{\circ} \mathrm{C}$ by the molybdenum blue method. Total phosphorus (TP) was analysed from the infiltrated sample as SRP after acid hydrolysis under UV irradiation. Non-reactive soluble phosphate (NRP) was quantified from the difference of TP and sum of SRP and PP. HCl-soluble particulate iron ( $\mathrm{PFe}$ ) was measured in the same $\mathrm{HCl}$ extract as described above for DFe.

For chlorophyll quantification, samples were filtered onto Whatman GF/F filters before extracting the filters in $3 \mathrm{ml} \mathrm{N}, \mathrm{N}$-dimethylformamide (DMF, Sigma). Absorption values were converted as described by Forster \& Schubert (2001). The relative content of carotenoids in all extracts with undetectable amounts of chl $b$ was calculated as carotenoid-chl a absorbance quotient $\left(\mathrm{A}_{487} / \mathrm{A}_{664}\right)$. The wavelength for carotenoids $(487 \mathrm{~nm})$ was selected as the best peak value fitting all measured extracts.

All point values for nutrients and pigments denote mean values of 3 analytical subsamples.

Phytoplankton analysis. Phytoplankton cells were counted in Lugol-fixed samples under an inverted microscope at 256-fold magnification. Solitary rodshaped cyanobacteria of the pico-size class $(<2 \mu \mathrm{m})$ were quantified in glutardialdehyde-fixed samples by epifluorescence microscopy (green light excitation BP $545 \mathrm{~nm}, 1250$-fold magnification), and a mean cell volume of $0.86 \mu^{3}$ (R. Schumann unpubl. data) was applied for biomass calculations. For cyanobacteria and Chlorophyceae, which form large spherical colonies, cell numbers were determined in 10 randomly-chosen colonies per sample under green light excitation at 1250 -fold magnification. From this mean cell number, the total cells per species and biomass were calculated. Cell volumes and carbon were estimated as described by Geiß et al. (2004). The morphological differentiation of taxonomic units was performed with the highest resolution possible (Anagnostidis \& Komárek 1988 for filamentous cyanobacteria; Pankow 1990). All identified species fell into the group of common species in the Darss-Zingst estuary (Wasmund 1994, Schumann et al. 2005). The occurrence of a new prochlorophyte species (Geiß et al. 2003) was irrelevant for morphological differentiations. Of the 42 morphotypes found in these samples, 10 probably represented more than 1 species but could not be differentiated quantitatively during counting. Solitary rod-shaped cyanobacteria were the most dominant 'unit', which was also reported as one species of a Synechococcus-like species by molecular methods (Geiß et al. 2004). Two abundant colonyforming Chroococcales, Aphanothece clathrata and Gomphosphaeria pusilla, each consisted of 3 to 4 species. A. clathrata included A. minutissima, Lemmer- manniella pallida and Cyanonephron styloides, which were also observed under high magnification and interference contrast as well as epifluorescence microscopy. The species-differentiating properties, cell size $(1-2 \mu \mathrm{m}$ or $<2 \mu \mathrm{m})$, mucoid stalks or hollow vs. filled colonies, were not visible under counting conditions. The Gomphosphaeria pusilla complex consisted of 2 Snowella and 2 Woronochinia species with rather weak distinctive features, such as more or less spherical cell form and more or less denselypacked colonies. Another abundant species, the filamentous Limnothrix cf. planctonica (without long sheaths at filament ends), also included a minor proportion of Planktolyngbya limnetica (with sheaths). Less abundant forms were Scenedesmus quadricauda, which could not be differentiated from several other species due to the prevailing unusual 2-cell coenobia, 2 groups of unicellular spherical green algae and 3 diatom morphotypes.

The number of different 16S rDNA fragments, which were selectively amplified by polymerase chain reaction (PCR) from plankton DNA for cyanobacteria and eukaryotic chloroplasts, was determined from 3 or 4 independent PCR analyses and denaturing gradient gel electrophoresis (DGGE) as described by Geiß et al. (2004).

Photosynthetic parameters. Fluorescence excitation spectra of photosystem II (PSII) emission (400 to $690 \mathrm{~nm}$, excitation: $720 \mathrm{~nm}$ ) and fluorescence emission spectra of phycobiliproteins and PSII (600 to $750 \mathrm{~nm}$, excitation: $570 \mathrm{~nm}$ ) were measured at room temperature $\left(22^{\circ} \mathrm{C}\right)$ with a modular spectrofluorometer $(\mathrm{C} 60$, Photon Technology; selected red-sensitive photomultiplier tube R928, Hamamatsu) in the photon-counting mode. Continuously stirred samples were treated with $10 \mu \mathrm{M}$ 3-(3', 4'-dichlorophenyl)-1,1-dimethylurea (DCMU) for $1 \mathrm{~min}$ to block electron transfer of PSII before the measurements were made to obtain maximum PSII fluorescence. This excluded background effects of the variable portions of PSII fluorescence $\left(F_{\mathrm{v}}\right)$ and led to a defined state of PSII for the comparison of all samples with respect to PSII-based fluorescence characteristics. All fluorescence spectra were corrected with system-specific correction files and background spectra of deionised water. Phycobilisome (PBS):PSII emission ratios were calculated with emission values at $655 \mathrm{~nm}$ and $685 \mathrm{~nm}$. PBS:chl $a$ excitation ratios of PSII emission were derived from the $720 \mathrm{~nm}$ emission values at $625 \mathrm{~nm}$ (phycocyanin-type phycobilisome) and $680 \mathrm{~nm}$ excitation. The excitation wavelength of $457 \mathrm{~nm}$ was selected for preferentially chl $b$-sensitive excitation of PSII emission to calculate chl $b: \mathrm{chl} a$ excitation ratios, accepting potential influences of $\mathrm{chl} C$ as well as of light-harvesting carotenoids. 
The efficiency of excitation energy capture by open PSII reaction centres was calculated with ${ }^{\circ} F_{0}$ as the minimum fluorescence yield when all primary stable electron acceptors of the PSII are oxidised after dark incubation and ${ }^{\circ} F_{\mathrm{m}}$ as the maximum fluorescence yield when all primary stable electron acceptors of PSII are reduced after a saturating light pulse: $\left({ }^{\circ} F_{\mathrm{m}}-{ }^{\circ} F_{\mathrm{o}}\right)^{\circ} F_{\mathrm{m}}{ }^{-1}$. This so-called 'photosynthetic capacity' (dark yield, maximum PSII efficiency, $F_{\mathrm{v}} F_{\mathrm{m}}{ }^{-1}$ ) was measured with a pulse-amplitude modulated chlorophyll fluorometer (Diving-PAM, Walz) after concentrating phytoplankton as described by Forster \& Schubert (2001). Corresponding measurements of the effective PSII quantum efficiency were made after acclimation to a certain irradiance $\left(\Delta F F_{\mathrm{m}}{ }^{\prime-1}\right.$, Kromkamp \& Forster 2003) for $3 \mathrm{~min}$ at $14,49,80,135,180,300,400,625,1000$ and $1400 \mu \mathrm{mol}$ photons PAR $\mathrm{m}^{-2} \mathrm{~s}^{-1}$, respectively.

Relative electron transport rates (rETR) were calculated with the formula: $\mathrm{rETR}=\Delta F F_{\mathrm{m}}{ }^{-1} \times \mathrm{PFD}$, with PFD in units of $\mu \mathrm{mol}$ photons $\mathrm{m}^{-2} \mathrm{~s}^{-1}$. Following the principal proportionality of chlorophyll fluorescence quenching and photosynthetic electron transport in a photosynthetic unit (e.g. Genty et al. 1989), photosynthesis/irradiance (P/E) curves were drawn using rETR values. The main parameters of photosynthesis were calculated by a last square fit of each P/E curve as given by Walsby (1997) with the Excel 2000 solver tool. The minimum irradiance level for the onset of lightsaturated photosynthesis $\left(E_{k}\right)$ was selected as an appropriate parameter for comparisons of irradiance acclimation on medium-term time scales (Sagert \& Schubert 2000).

For calculations of the relative gross primary production (rGPP) per day at a station, the numerical integration of rETR values through time and depth in the water column was done basically as described by Walsby (1997). Because of the relative expression of photosynthesis, only those relevant parameters that differentiated the stations were used for calculations, i.e. the parameters of the P/E model for the phytoplankton sample, $k_{\text {PAR }}$ and chl a concentration. The resolution of the water column was limited to $0.1 \mathrm{~m}$ depth intervals. The temporal resolution was set to $0.5 \mathrm{~h}$ intervals. For the same intervals, mean values of incident PAR were used for calculations of PAR at the different depth intervals. Final numerical values have no relevance for inter-system comparisons and have been divided by $10^{3}$ for graphical presentation. The influence of the different PAR courses on the 2 sampling days on the results led to a low deviation $(3.5 \pm 0.4 \%, \mathrm{n}=10)$ of the mean of the 2 different rGGP values.

Statistical analysis. The Shannon-Wiener diversity index $\left(H^{\prime}\right)$ and, with special respect to the evaluation of community diversity along gradients, turnover (beta) diversity $\left(\beta_{\mathrm{S}}\right)$ were calculated as reported by Gray
(2000). Turnover diversity measures the change in composition of samples along a gradient with the algorithm $\beta_{\mathrm{S}}=\mathrm{SR}_{\mathrm{S}} / \mathrm{SR} \mathrm{R}_{\overline{\mathrm{P}}}$, where $\mathrm{SR}_{\mathrm{S}}$ is the total number of species found in a sample and $\mathrm{SR}_{\overline{\mathrm{P}}}$ is the mean number of species within the point samples. The preference for $H^{\prime}$ in comparison to other species diversity indices resulted from its frequent use in phytoplankton diversity studies and its comparatively low sensitivity to dominance, i.e. to the first 2 or 3 species of the rank sequence of species (Gray 2000). In this way, the impact of the abundant Synechococcus-like unit was suppressed in advance. The use of biomass for calculations of $H^{\prime}$ reflects the fact that regional datasets for coastal phytoplankton in the Baltic Sea have been made compatible to each other by biomass (e.g. Gasiūnaitè et al. 2005). Thus, the $H^{\prime}$ data will be compatible to any large-scale species diversity analysis in the future, which most probably will also use biomass. The second method of $H^{\prime}$ calculation pays attention to 'individuals', but the strict definition probably restricts comparisons of $H^{\prime}$ values to this study and re-evaluated data from other studies. This will be discussed in more detail below.

If no other information is given in the text, correlation coefficients were calculated for linear regression models of all observations $(\mathrm{n}=10)$. Square brackets indicate recalculated values for analyses without the value from Stn 1 at the mouth of the Recknitz River ( $\mathrm{n}=$ 9), as this station often showed unique features compared to all other stations in the semi-enclosed estuarine basins.

\section{RESULTS}

\section{Abiotic and biotic parameters}

Sampling days represented the seventh and ninth days of a clear-sky period with low day-to-day variability (Fig. 2A) of the incident daily PAR dose (17 to 25 July; mean: $45.4 \pm 2.5$, range: 43.1 to $50.6 \mathrm{~mol}$ photons $\mathrm{m}^{-2} \mathrm{~d}^{-1}$ ). Therefore, the medium-term PAR dose was very similar on the sampling days and reached values at the upper limit for July (Fig. 2A). Short-term maximum values (30 min average) of incident PAR were 1437 and $1521 \mu \mathrm{mol}$ photons PAR m ${ }^{-2} \mathrm{~s}^{-1}$ in the early afternoon on 23 and 25 July, respectively (Fig. 2B). Along the transect, water temperature was between 22 and $25^{\circ} \mathrm{C}$. Short-term variability at a single site could be expected to be low, since automatic measurements at a reference site (Biological Station Zingst) indicated a daily amplitude of 1.4 to $1.8^{\circ} \mathrm{C}$ for both sampling days (data not shown). Wind velocities from 20 to 26 July never exceeded the critical limit for sediment re-suspension $\left(6 \mathrm{~m} \mathrm{~s}^{-1}\right)$. Velocities above 

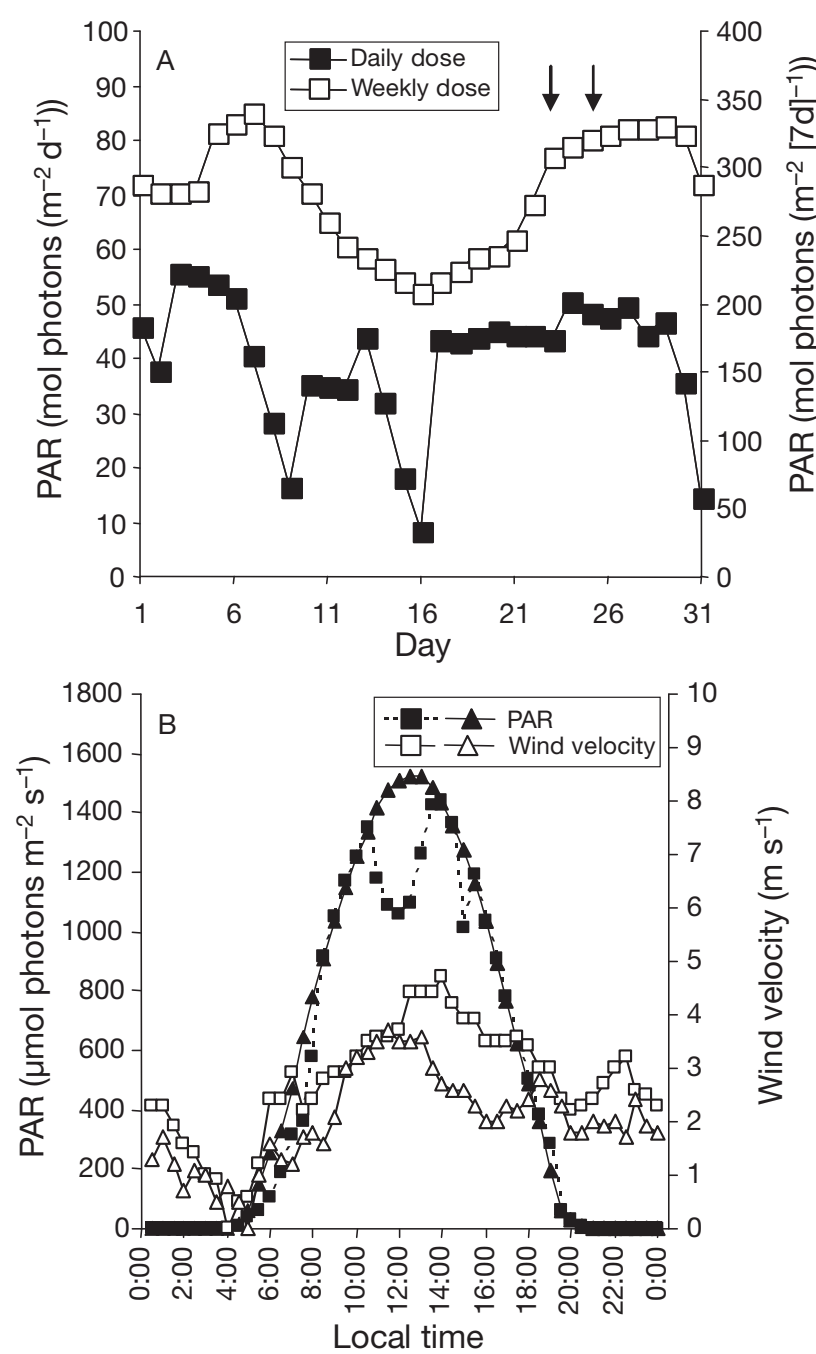

Fig. 2. (A) Weekly and daily PAR dose in July and (B) courses of PAR and wind velocity on 23 July (squares) and 25 July (triangles). Symbols for the weekly PAR dose denote sum of PAR for the respective day and 6 preceding days. Symbols in B represent mean values from 30 min data sets. Arrows mark sampling days

$3 \mathrm{~m} \mathrm{~s}^{-1}$, the limit for complete vertical mixing, prevailed on 23 and 25 July both a few hours before (beginning at about 09:00 h) and during most of the sampling periods (Fig. 2B).

Continuous gradients of dissolved inorganic nutrients were absent along the salinity gradient of the Darss-Zingst estuary in summer (Table 2). Except in the river mouth (Stn 1), all SRP concentrations were lower than $0.5 \mu \mathrm{mol} \mathrm{l}^{-1}$. Maximum NRP concentration $\left(2.6 \mu \mathrm{mol} \mathrm{l}^{-1}\right)$ occurred at the station with maximum phytoplankton biomass (Stn 3). DIN concentrations correlated with calculated values from the salinityderived water exchange, but not for the entire transect. Starting with the maximum DIN value of Stn 4 as the innermost station of the water basins, the correlation became significant $(\mathrm{r}=-0.900, \mathrm{p}<0.02, \mathrm{n}=7)$. The variability of DIN concentration in the water basins was mainly determined by variations in $\mathrm{NH}_{4}{ }^{+}$concentration. $\mathrm{NH}_{4}{ }^{+}$reflected 58 to $98 \%$ of DIN, and nitrate was the dominating fraction only in the river mouth (Stn 1; data not shown).

DOC concentrations strongly correlated with phytoplankton biomass $(\mathrm{r}=0.959, \mathrm{p}<0.001)$. The regression analysis [ $\mathrm{r}=0.991, \mathrm{p}<0.001, \mathrm{n}=9]$ revealed a constant DOC-specific absorption coefficient for ultraviolet radiation at $250 \mathrm{~nm}$ in all samples from Stns 2 to 10 (50.8 $\mathrm{mg} \mathrm{l}^{-1} \mathrm{~cm}^{-1}$ ) and an absorption-ineffective background of $2.5 \mathrm{mg} \mathrm{l}^{-1}$. Assuming the same absorptionineffective DOC background at Stn 1, the DOCspecific absorption coefficient in the river water was $22.3 \mathrm{mg} \mathrm{l}^{-1} \mathrm{~cm}^{-1}$, i.e. the mass-specific absorption strength of DOC was about twice as high as in the water basins.

DFe concentrations were highly variable along the salinity gradient, and neither DOC concentrations nor biomass-dependent parameters gave any evidence for correlations that would explain the variability. However, the contribution of DFe to the total iron pool decreased with increasing $\mathrm{pH}$ values in the water basins (Fig. 3). This correlation was not just a simple reflection of changes in the composition of particulate organic matter by e.g. changing phytoplankton composition, since corresponding correlations with $\mathrm{pH}$ values were insignificant (data not shown).

In contrast to the dissolved phase, high concentrations of nitrogen and phosphorus accumulated in the particulate phase in summer, especially in the highly eutrophic westerly part of the estuary (Table 2). POC and phytoplankton biomass were correlated $(\mathrm{r}=0.951$, $\mathrm{p}<0.001, \mathrm{n}=10$ ), although phytoplankton carbon mostly represented less than $20 \%$ of POC.

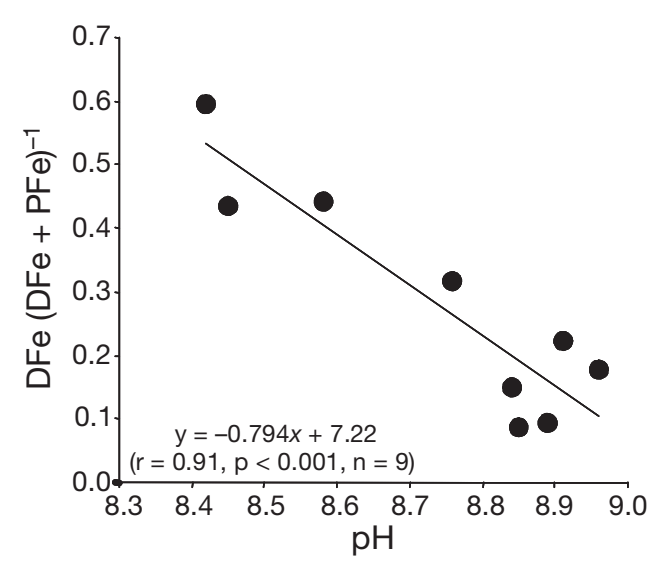

Fig. 3. Dependence on $\mathrm{pH}$ of contribution of dissolved iron (DFe) to total iron at sampling sites in semi-enclosed water basins 
Table 2. Longitudinal pattern of physical and chemical parameters in the pelagial of the Darss-Zingst estuary during a midsummer clear-sky period. Values for dissolved and particulate matter are given in $\mu \mathrm{mol}^{-1}$. Element ratios were calculated with moles. Point values for absorbance and matter parameters represent mean values of 3 analytical subsamples. PAR: photosynthetically active radiation, DOC: dissolved organic carbon, DIN: dissolved inorganic nitrogen, SRP: soluble reactive phosphorus, NRP: nonreactive soluble phosphate, DFe: dissolved iron, POC: particulate organic carbon, PN: particulate nitrogen, PP: particulate phosphorus, PFe: particulate iron

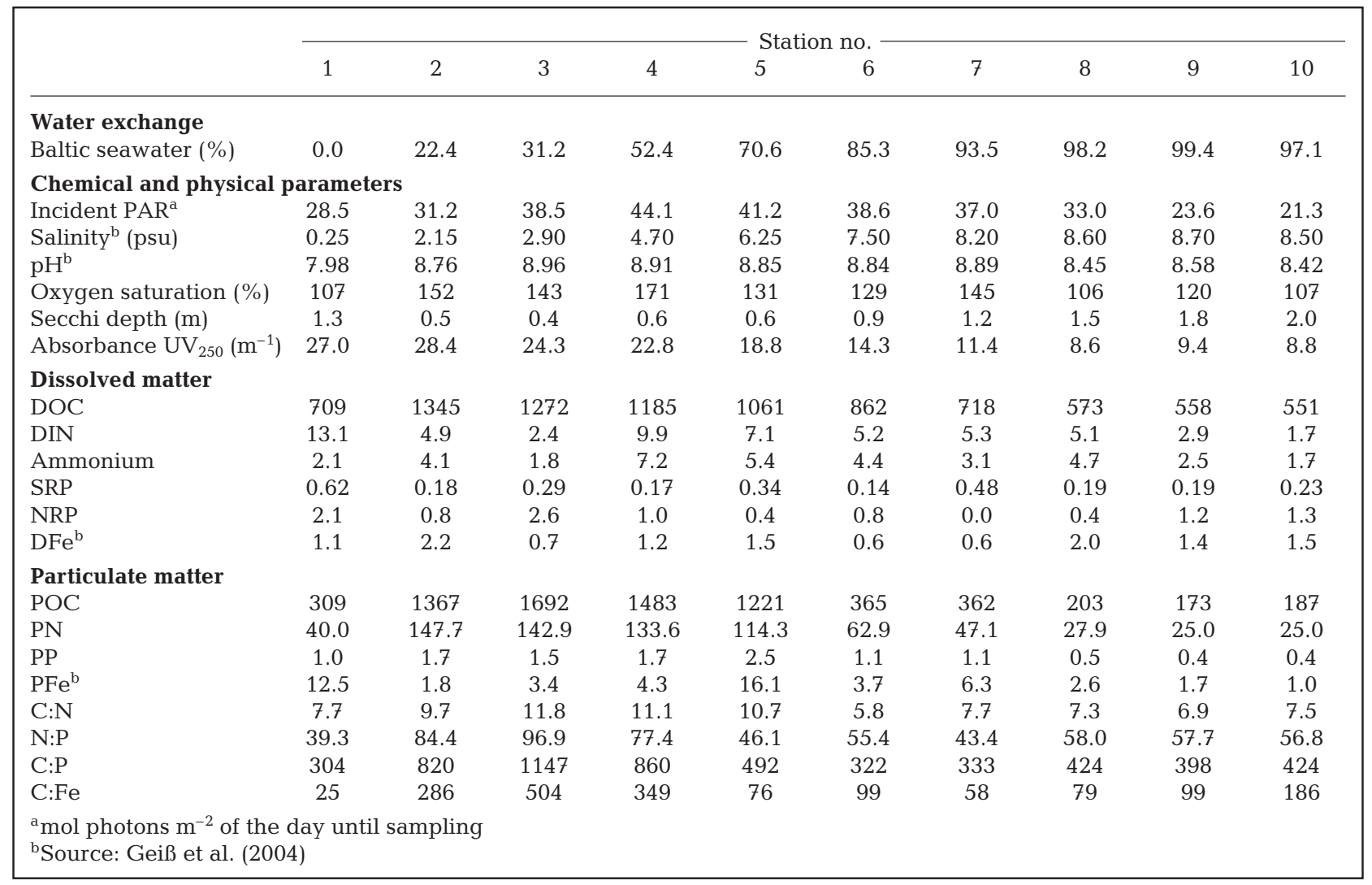

A clear decrease in POC concentration (Table 2) and phytoplankton biomass with increasing salinity was limited to the salinity range of 3 to 8 (Stns 4 to 10). This was accompanied by changes in the element ratios of particulate matter (Table 2). Excluding Stn 1, 2 respective groups were distinguished: Group 1 (Stns 2 to 5), consisting of the 4 stations with high phytoplankton biomasses, was characterised by 1.5 - to 3-fold enhanced element ratios (C:N, C:P, N:P) compared to Group 2 (Stns 6 to 10). Maximum ratios were found at Stn 3. Due to the exceptionally high PFe concentration at Stn 5 (Table 2) only the innermost stations (Stns 2 to 4) provided 3- to 5-fold enhanced ratios for C:Fe compared to the average of the other stations, but the maximum value again was calculated for Stn 3.

Although high levels of relative gross primary production on sampling days (Fig. 4) coincided with high concentrations of POC and maximum values of oxygen oversaturation in the westerly parts (Stns 2 to 4 ; Table 2), Stn 5 provided unusually high values. Calculating relative gross primary production for a mean standard water

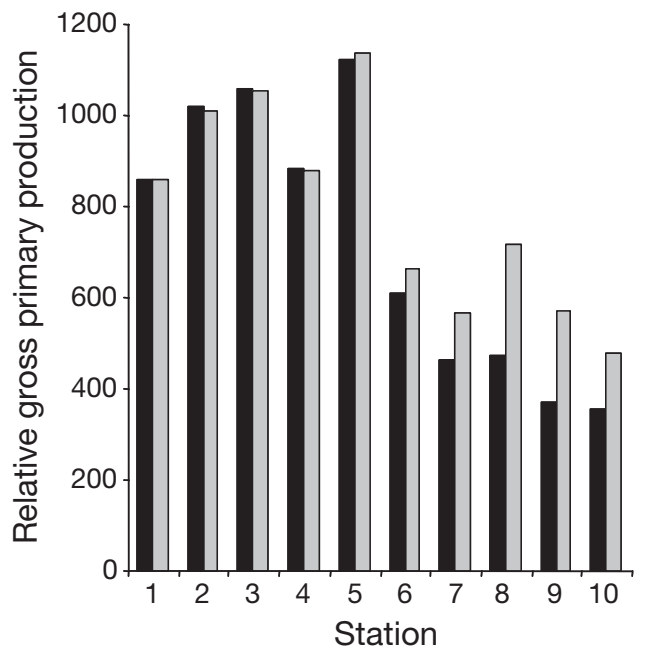

Fig. 4. Relative gross primary production per day as integrals for a model water depth of $2 \mathrm{~m}$ (black columns) and for a variable water depth down to the depth limit of the photic zone (grey columns). For calculation procedures, see 'Materials and methods' 
depth of $2 \mathrm{~m}$ and for the maximum water depth of the photic zone (Fig. 4), only Stns 6 to 10 indicated potential primary production at water depths exceeding the low mean water depths (Table 1) of the water basins.

\section{Composition and diversity of phytoplankton communities}

Maximum phytoplankton biomass was detected in the innermost parts of the estuary (Stns 2 and 3) with 8to 9-fold higher values than that obtained from the river inflow at Stn 1. The successive decrease of phytoplankton biomass towards the Baltic Sea spanned differences of up to about $400 \%$ with respect to the minimum values at Stns 9 and 10 (Fig. 5). A pronounced change of biomass-based phytoplankton composition could not be observed in the main parts of the estuary along its west-east expansion. Phytoplankton biomass in the main water bodies (Stns 2 to 10) was dominated by cyanobacteria (mean $77 \pm 10 \%$ ), and the remaining portion of biomass predominantly resulted from Chlorophyceae (Fig. 5). Diatoms accounted for only a few percent of the total biomass. Autotrophic flagellates (Cryptophyceae, Dinophyceae) were present in significant amounts at Stn 1 only, which is mainly influenced by riverine input. At this station, the percentage of cyanobacterial biomass was below $50 \%$.

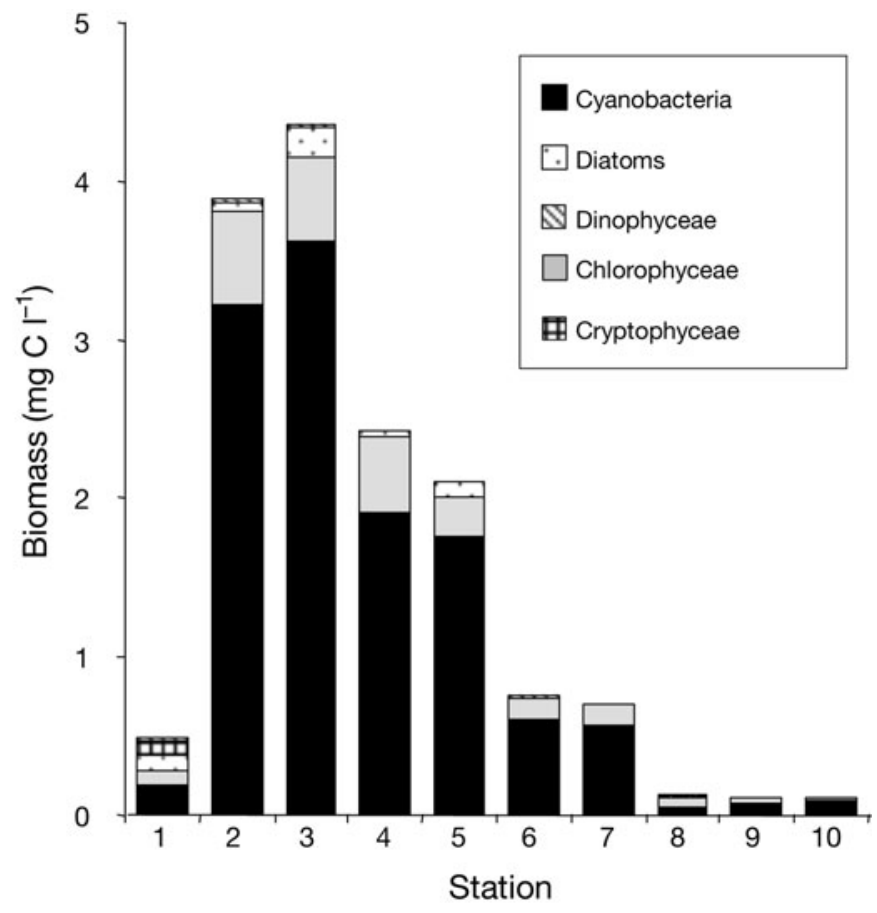

Fig. 5. Contribution of higher taxa to phytoplankton biomass in the estuarine pelagial. The fraction of cyanobacterial biomass corresponds to the total biomass of cyanobacterial groups reported by Geiß et al. (2004)
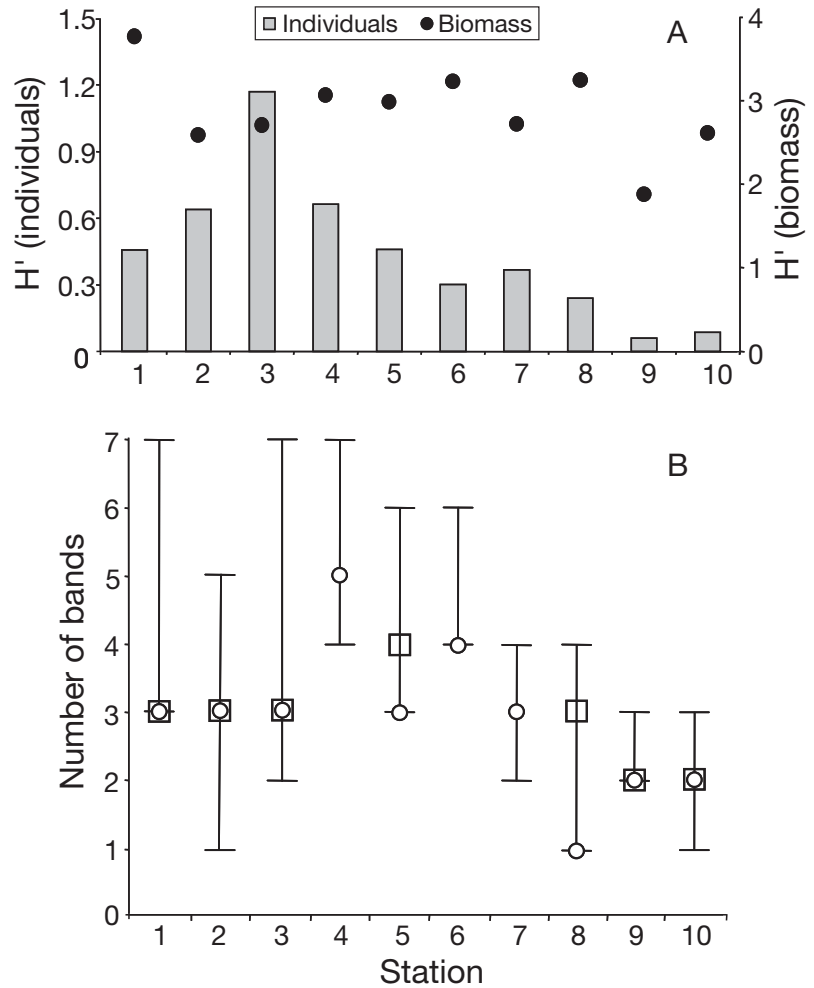

Fig. 6. (A) Phytoplankton diversity index $\left(H^{\prime}\right)$ based on biomass and number of individuals; (B) spread of detectable numbers of 16S rDNA-DGGE bands as a measure of the richness in phytoplankton-dominating genotypes. Single symbols (horizontal lines, squares, circles) represent 1 number of bands in a separate DGGE gel for 1 independent 16S rDNA amplification $(\mathrm{n}=3-4)$

On average, phytoplankton communities consisted of 24 species. Scaling the total number of species per sampling site (range 17 to 29 ) to the horizontal expansion of the estuary revealed no clear trend with respect to increase and decrease of species richness (data not shown). Of a total of 42 species observed, 26 occurred at least $50 \%$ of the sampling sites. A ubiquitous distribution was limited to 12 species. Just 8 species showed an exclusively continuous distribution that covered at least 3 successive stations of the transect. A further 9 species displayed continuous distributions for at least 3 successive stations, but appeared sporadically at other stations. All other species appeared rarely or without a describable pattern.

The biomass-based Shannon-Wiener index $\left(H^{\prime}\right)$ indicated a marked loss of diversity at the transition zone from fresh to brackish water, and almost negligible changes occurred along the transect of the estuarine basins (Stns 2 to 8, Fig. 6A). The minimum value was reached close to the outer coastline (Stn 9). However, the value at the most westerly sampling site (Stn 10) fell into the average range. This is probably attributable to 
the transition zone with neighbouring, semi-enclosed water, since salinity was slightly lower than at Stn 9 (Table 2). Biomass-independent information units were obtained when counting individuals. Individuals could be represented as 2 cells in a cyanobacterial filament or of 12 cells in another filament, 5 cells in a colony-forming green alga, a single large diatom or a single small Synechococcus-like cell, but species remained as basic categorisation units of these individuals. Using this categorisation for calculations, $H^{\prime}$ peaked at Stn 3. An almost continuous decrease of $H^{\prime}$ occurred from Stn 3 to the outermost Stn 10 (Fig. 6A). A rough estimate of the richness in dominant genotypes of phytoplankton by detectable 16S-rDNA-PCR fragments in DGGE analyses (Fig. 6B) indicated the tendency of enhanced richness at freshwater inflow and highly productive sites (Stns 1 to 6) compared to less productive stations in the transition zone to the Baltic Sea (Stns 7 to 10). Also, turnover diversity (range: 0.69 to 1.18$)$ peaked with the maximum values (1.18) at highly productive stations (Stns 3 and 5). The minimum value was obtained for the sampling site close to the open coastline of the Baltic Sea (Stn 9).

Regarding calculations of the number of individuals, values of $H^{\prime}$ and total phytoplankton biomass correlated significantly (Fig. 7) in contrast to other calculations for $H^{\prime}$ in relation to species-specific biomass or cell number respectively (data not shown).

\section{Photosynthetic acclimation of phytoplankton communities}

The photosynthetic capacity $\left(F_{\mathrm{v}} F_{\mathrm{m}}{ }^{-1}\right)$ of phytoplankton from the main water bodies was low (Stns 2 to 10, mean: $0.26 \pm 0.04$, range: 0.18 to 0.32 ). Only phyto-

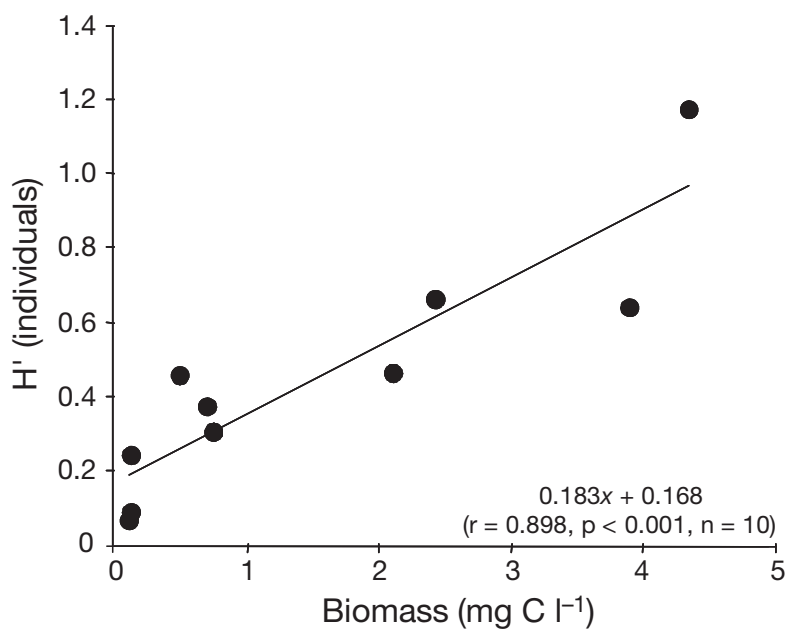

Fig. 7. Phytoplankton diversity $\left(H^{\prime}\right)$ based on number of individuals dependent upon phytoplankton biomass concentration

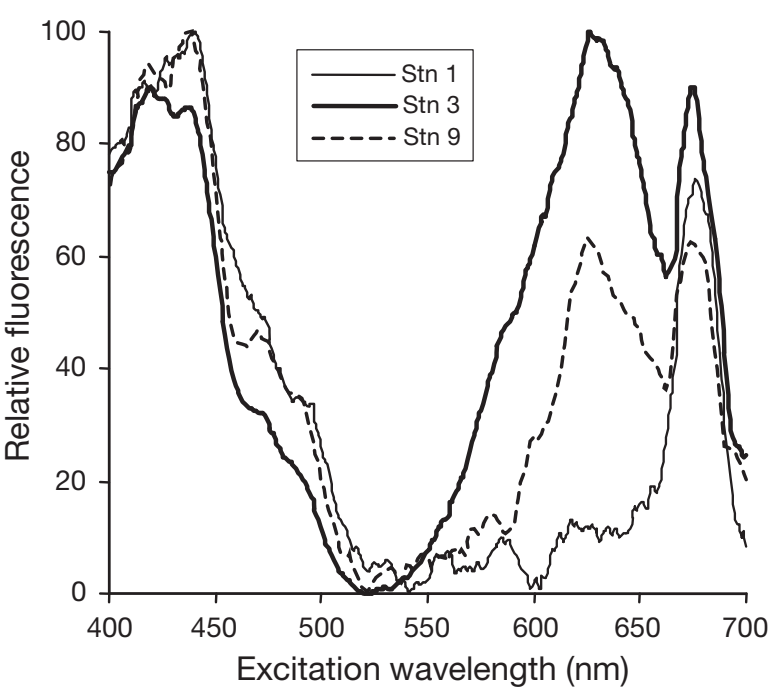

Fig. 8. Selected PSII fluorescence spectra of DCMU-treated phytoplankton from the river mouth (Stn 1), the semienclosed basin with maximum biomass concentration (Stn 3), and the sampling site close to the Baltic Sea coastline (Stn 9). All spectra were scaled relative to the variable signal range for comparison of divergent signal levels

plankton in the river water exhibited a higher photosynthetic capacity (0.47). PSII excitation spectra in vivo generally indicated phycocyanin (PC) as the main light-harvesting antenna pigment of PSII besides chl a for phytoplankton in the semi-enclosed basins (Fig. 8). The longitudinal gradient of $k_{\text {PAR }}$ correlated with chl a concentration $(\mathrm{r}=0.947, \mathrm{p}<0.001$; $[\mathrm{r}=0.968, \mathrm{p}<$ 0.001]). A significant correlation of PC:chl a excitation ratios of PSII fluorescence and PC:PSII fluorescence emission ratios $(\mathrm{r}=0.869, \mathrm{p}<0.005)$ excluded pronounced changes in energy transfer efficiency between phycobilisomes and PSII in the phytoplankton along the $k_{\text {PAR }}$ gradient. However, maximum ratios at Stns 3 and 4 indicated an enhanced chl a-normalised PC content at stations with high PAR attenuation in the water bodies (data not shown). To test whether the cyanobacteria-dominated phytoplankton acclimates to irradiance by the regulation of chl a content rather than by the regulation of peripheral light-harvesting antenna pigments, biomass-specific chl a content was compared to $k_{\mathrm{PAR}}$. Values of biomass-specific chl a content for sampling sites with the highest irradiance attenuation were 40 -fold lower compared to the site with the lowest attenuation. All values showed a surprising negative correlation with increasing $k_{\mathrm{PAR}}$ (Fig. 9A). Due to almost stable proportions of higher phytoplankton taxa at the different sampling sites, the correlation may be explained by the varying proportions of unicellular picocyanobacteria of the Synechococcus type. Their percentage in the total biomass 
could contribute up to about $97 \%\left(\mathrm{r}^{2}=0.967\right)$ of the total variability in the biomass-specific chl a content of the phytoplankton. A more than 100-fold higher biomass-specific chl a content of picocyanobacteria in comparison to the remaining average phytoplankton could then be derived from the regression model (Fig. 9B), since positive correlations with relative dominances of other significant taxa or groups (e.g. chroococcoid colony-forming cyanobacteria) did not exist.

Despite the measurable contribution of Chlorophyceae to total phytoplankton biomass (Fig. 5), chl $b$ concentrations were too low for quantification in DMF extracts of phytoplankton-loaded filters. Thus, the ratio of PSII fluorescence values from DCMU-treated phytoplankton samples at preferentially chl $b$ - and chl $a$ exciting wavelengths served as a relative measure of necessarily expectable trace amounts of chl $b$. The decline in chl $b: \mathrm{chl} a$ excitation ratios with increasing $k_{\text {PAR }}$ (Fig. 9C) indicated an additional decrease of chl $b$ content despite the decrease in biomass-specific chl a content. The decreasing proportions of picocyanobacteria should lead to increasing $\mathrm{chl} b: \mathrm{chl} a$ excitation ratios if chl $a$-normalised chl $b$ contents of Chlorophyceae do not decline with increasing $\mathrm{k}_{\mathrm{PAR}}$.

Neither saturation irradiance of photosynthesis $\left(E_{k}\right)$, an integral measure of different irradiance acclimation mechanisms, nor chl a-normalised content of total carotenoids showed significant correlations with $k_{\text {PAR }}$ (data not shown). However, phytoplankton from the water basins provided a weak but significant positive correlation of both parameters with an unexpected order of sampling stations (Fig. 9D). This sign of varying irradiance acclimation led to a closer inspection of the shortterm variability of irradiance climates between the different samples. Although the selection of clear-sky periods reduced the variability of the irradiance climate in general at different sampling sites and times, each sampling interval of a day took 3 to $5 \mathrm{~h}$. Calculating the incident PAR dose of the day at the water surface exactly until sampling took place (mean value: $33.7 \pm 7.5 \mathrm{~mol}$ photons PAR $\mathrm{m}^{-2}$ ), differences of up to $100 \%$ were obtained for 2 samples in the worst case. Daily incident PAR dose (sunrise to sampling time) and chl a-normalised carotenoid content $\left(\mathrm{A}_{487} / \mathrm{A}_{664}\right)$ showed detectable correlation for the whole data set $(r=0.700, p<0.05)$. This correlation became markedly stronger when the outstanding value of Stn 1 at the river mouth was excluded $(\mathrm{r}=0.847$, $p<0.005$ ). The same holds true for the correlation of PAR dose and $E_{k \prime}$ but only when one completely outlying value (Stn 4) was omitted ( $\mathrm{r}=0.857, \mathrm{p}<0.005$, $\mathrm{n}=9$ ). These correlations were completely lost when values of incident PAR dose until sampling were weighted by $k_{\mathrm{PAR}}$ values from the corresponding sampling sites. In contrast to phytoplankton biomass and related parameters, values of the incident PAR dose until sampling correlated with $\mathrm{pH}$ values in the central basins significantly $(\mathrm{r}=0.817, \mathrm{p}<0.01)$.

\section{DISCUSSION}

\section{Water chemistry and nutrient regime}

On average, the input of nutrients in the Darss-Zingst estuary by river water amounts to $1807 \mathrm{t}$ nitrogen and $47 \mathrm{t}$ 
phosphorus per year (Behrendt et al. 1999). As a consequence of the discharge regime, dissolved nutrients are predominantly transported in winter and spring. In summer, the low runoff into the estuary and high productivity of macrophytes in the river lead to a relatively low nutrient supply. There are many gaps in understanding the framework by which phytoplankton diversity and primary production are determined under these special conditions. During the investigations in summer 2001, high potential primary production in the inner estuarine system was suggested by point values of oxygen oversaturation (Table 2). The element composition in respect to macronutrients $(C$, $\mathrm{N}, \mathrm{P}$ ) of the particulate pool as well as the SRP concentration indicated a potential phosphorus Redfield limitation (e.g. Urabe 1993) in this shallow water system in spite of well-mixed water bodies. SRP concentrations in the water column of the estuary are primarily determined by physico-chemical reactions with the sediment of high sorption capacity (Schlungbaum \& Nausch 1988). In summer, prevailing oxidation of the upper sediment, which is rich in iron (Nausch \& Schlungbaum 1977), most probably explains a relatively low SRP release. Even when wind velocities reach the limit $\left(6 \mathrm{~m} \mathrm{~s}^{-1}\right)$ of sediment resuspension (cf. Fig. 2B), preferential suspension of oxidised particles from the upper sediment surface and rapid re-oxidation of disturbed sediment layers may explain the low SRP concentrations in the pelagial in spite of a large phosphorus storage in the sediment. Potential phosphorus depletion of biomass is more evident when ratios of macronutrients in the particulate pool are calculated on the basis of carbon, which was estimated from biovolume of phytoplankton and bacterioplankton (data not shown) instead of POC, since all but the C:P ratios (range: 42 to 260 ) fell markedly below Redfield ratios. DIN concentrations were higher than previously determined in the early summer season of 1992 (A. Schoor unpubl. data). Decoupling of $\mathrm{N}$ assimilation from carbon fixation or its temporal shift in the daily course seemed to be an effect of the limiting of nutrients or an unfavourable irradiance climate.

The role of iron as a micronutrient is not well understood in highly productive estuaries. High total iron concentrations often seem to exclude influences of iron nutrition on productivity. The correlation of $\mathrm{pH}$ and proportion of DFe in the total iron pool of the water basins (Fig. 3) may suggest significant influences of biological activity on the iron distribution in the pelagial. The data do not allow a simple conclusion in regard to whether these are direct and/or indirect effects of primary production. These include the assimilation of $\mathrm{DFe}$ into the particulate pool and/or $\mathrm{pH}$ dependent precipitation of DFe as inorganic particles, which lead to their more efficient separation by filtra- tion. Even when all of the DFe represents bioavailable iron, the minimum concentrations in the estuary $\left(0.6 \mu \mathrm{mol} \mathrm{l}^{-1}\right)$ can induce the iron starvation response of the moderately salinity-resistant freshwater cyanobacterium Synechocystis sp. PCC 6803 (Geiß et al. 2001a). In autumn, iron fertilisations of phytoplankton from the Darss-Zingst estuary generally reduced stress to PSII (Pilkaitytë et al. 2004). Expression studies of a cyanobacterial iron stress gene (Geiß et al. 2004) showed that at least some cyanobacteria must suffer from restricted iron supply in summer. However, whether this affected net primary production and growth of the phytoplankton community remained unclear. Empirically-obtained element ratios in the nutrient pool, which may reflect phytoplankton iron nutrition in eutrophic waters, are unknown. Relatively high Fe:P molar ratios $\left(10^{-1.4}\right.$ to $\left.10^{-2.7}\right)$ in the dissolved pool induced limitation changes of oceanic and coastal cyanobacterial strains (Brand 1991). Corresponding values (DFe:SRP) in this study $\left(10^{0.2}\right.$ to $\left.10^{1.1}\right)$ did not reach such critical values, but their interpretation has an important drawback owing to the occurrence of significant amounts of dissolved phosphorus other than SRP. The strong phosphate-binding affinity of iron(III) colloids can have a large effect on the speciation of phosphorus; extent and rate of formation of iron(III) colloids is drastically affected by iron-DOM interactions (Pullin \& Cabaniss 2003). Including the special fraction of dissolved P (NRP) as 'bioavailable', as it was artificially done for $\mathrm{DFe}$, the minimum ratio reached $10^{-0.6}$ at the station with maximum phytoplankton biomass. The ratio could easily fall short of the above mentioned critical level when significant proportions of this kind of dissolved phosphorus form insoluble (ferric) compounds at alkaline $\mathrm{pH}$ in situ, which pass filters for the preparation of dissolved fractions but are not readily available to phytoplankton. References for iron quota in the particulate pool of waters with a high dominance of colony-forming cyanobacteria are rare. Gerloff \& Skoog (1957) compared iron contents per dry weight of Microcystis blooms in different lakes. All samples (146 to $543 \mathrm{ppm}$ ) exceeded the estimated value of $100 \mathrm{ppm}$ for the onset of growth limitation. Corresponding calculations for seston (data not shown) of the estuarine basins led to iron concentrations in the range of 3453 to $11677 \mathrm{ppm}$ with the minimum value at the site with maximum biomass concentration (Fig. 5). In general, restricted iron nutrition of cyanobacteria, which was derived from gene expression studies (Geiß et al. 2004), cannot be simply supported by the elemental composition of dissolved and particulate pools. However, current investigations on cyanobacterial blooms on the Baltic Sea coast indicate that the majority of PFe can represent an extracellular fraction (B. Schubert unpubl. data). Similar proportions 
may suggest intracellular iron concentrations in the particulate pool of the Darss-Zingst estuary at the potentially critical level of 100 ppm (Gerloff \& Skoog 1957), since salinity-mediated precipitation of dissolved iron from river water makes a higher importance of extracellular PFe likely. The comparably high UV absorption strength of DOC in the river mouth indicates higher proportions of humic acids than in the estuarine DOC. The sharp decrease in total iron at the onset of increasing salinity suggests that net removal of iron is also mediated by aggregation of (humic) iron colloids owing to changes in salinity and $\mathrm{pH}$. The shallow estuary seems to share this physically and chemically driven process with other estuarine systems (e.g. Forsgren et al. 1996). Assumptions that exceptionally high concentrations of DOC in the low saline basins (Table 2) suppress iron precipitation from river water to a very great extent must be rejected.

\section{Photosynthetic acclimation and phytoplankton diversity}

The irradiance climate in the water bodies of the shallow Darss-Zingst estuary varies on many different levels (Schubert et al. 2001). Although responses of the phytoplankton community to selected levels of variability (spectral shift, UV exposition) were investigated in experimental systems and at selected locations (Schubert et al. 1995, Forster \& Schubert 2001), the different levels of variability usually prevent a simple inspection of phytoplankton irradiance acclimation along the longitudinal transect. In the present approach, some significant sources of variability were reduced by the selection of the sampling period and sampling scheme. The values of photosynthetic capacity $\left(F_{\mathrm{v}} F_{\mathrm{m}}{ }^{-1}\right)$ in the semi-enclosed basins fall into the range of the lowest values that can be measured in the estuary (Schubert \& Forster 1997). They can be assigned to the high percentage of cyanobacterial phytoplankton for several reasons, e.g. specificity of the photosynthetic state in darkness (Campbell \& Öquist 1996), but also limits of PAM measurements for the discrimination of phycobiliprotein fluorescence emission and PSII emission. The latter seemed to be of minor importance for slight differences of the values during our investigations, since decreasing photosynthetic capacity with an increasing PC:PSII fluorescence emission ratio in the set of phytoplankton samples was not observed (data not shown). In addition, significant drawbacks of PAM measurements predominantly can be assumed for cyanobacteria with artificially high phycobiliprotein content due to cultivation in the laboratory (Campbell et al. 1998), but the dominance of the PBS antenna (Fig. 8) in phytoplankton of the Darss-
Zingst estuary was lower in comparison to similar samples with higher $F_{\mathrm{v}} F_{\mathrm{m}}^{-1}$ values (e.g. Pilkaitytë et al. 2004). Thus, the very low values of photosynthetic capacity may be assigned to cyanobacteria that are locked in state I (Campbell \& Öquist 1996) and/or that are subject to severe stress (nutrient deprivation, oxidative agents), affecting photosynthetic performance directly. Possibly, shadowing by terrestrial and aquatic higher plants, high nutrient concentrations, and the comparably high percentage of photosynthetic eukaryotes (Fig. 5) may be responsible for the higher photosynthetic capacity of phytoplankton in the river mouth.

Irradiance attenuation in the water column characterised a steep gradient along the west-east expansion of the estuary. A photosynthetic acclimation to the respective changing underwater irradiance climate could not be shown, although wind velocities indicated well-mixed water bodies. The superimposition of a changing proportion of unicellular picocyanobacteria and a gradient of irradiance attenuation prevented any analysis with respect to irradiance acclimation by regulation of chl a content. In addition, spectrofluorometric analyses failed to detect differentiations in the excitation transfer efficiency from phycobilisomes to PSII, although maximum chl a-normalised PC excitation (emission) indicated increased PBS antenna size at the few sampling sites with maximum irradiance attenuation in the water column. Thus, the weak correlations of irradiance dose until sampling and $E_{k}$ as well as chl a-normalised carotenoid content support tuning of photosynthetic acclimation at high incident irradiance in a dose-dependent manner. The probable impact of nutrient limitation on the variation in chl a-normalised carotenoid content has been investigated and discussed by Schlüter et al. (1997). Correlations with respective element ratios in the particulate pool were absent (data not shown), i.e. irradiance acclimation of the phytoplankton seems to depend at least partially on the total time of exposure to irradiance above a critical, probably photoinhibitory, level. Shadowing by vertical mixing is inefficient to induce recovery of PSII quantum efficiency or to induce it to a significant extent until afternoon. A rapid acclimation by synthesis of protective carotenoids on the scale of hours can be attributed to cyanobacteria. Pigment turnover experiments characterised the fast new synthesis of main carotenoids and a steady-state level within 20 to 100 min after onset of irradiance stress, while Chlorophyceae showed a slow and ongoing response up to $8 \mathrm{~h}$ (Schubert et al. 2003). This kind of dose-dependent irradiance acclimation on a short-term scale is unusual for phytoplankton in mixed water bodies of mesotrophic-eutrophic waters, since vertical mixing is thought to decrease residence time at the water 
surface and photoinhibition, respectively (Franks \& Marra 1994). In well-mixed estuaries, phytoplankton cells adapt themselves to a mean light environment (e.g. MacIntyre \& Cullen 1996). However, a dosedependent effect could also be assumed due to the daily course of variable chlorophyll fluorescence, which was previously measured under similarly clear sky conditions at a single location of the Darss-Zingst estuary in 1994 (Schubert \& Forster 1997). Minimum values of variable PSII fluorescence in summer 1994 (about 0.25) occurred hours after the irradiance maximum at noon. Nevertheless, our data indicated no recovery of the low variable fluorescence, although samples were stored for 4 to $6 \mathrm{~h}$ until measurements were done. Thus, other factors should have acted simultaneously, since even green algae show recovery of PS II with a half-time of about $1 \mathrm{~h}$ after chronic photoinhibition (e.g. Neidhardt et al. 1998).

The above-mentioned, potentially critical iron nutrition of the cyanobacteria-dominated phytoplankton and the detection of cyanobacteria expressing the iron stress gene isiA (Geiß et al. 2004) led us to the hypothesis that weak recovery of variable PSII fluorescence in the dark could be attributed to the synthesis of the IsiA protein in cyanobacteria. The synthesis of this protein leads to strong fluorescence emission in the common emission band of PSII (685 nm). This reduces $F_{\mathrm{v}} F_{\mathrm{m}}{ }^{-1}$ values consistently in different cyanobacteria under iron starvation (e.g. Öquist 1974, Geiß et al. 2001b) and can hamper the characterisation of functional PSII units, which get IsiA-mediated protection against overexcitation by fluorescence emission. This may explain the positive correlation of $\mathrm{pH}$ as a measure of phytoplankton productivity and incident PAR dose until sampling against the background of a generally low level of PSII quantum efficiency. Furthermore, synergism of photoinhibitory irradiance and nutrient deprivation provides a solution to understand the extraordinarily low importance of chl $b$, even at stations with maximum $k_{\text {PAR }}$ or proportions of Chlorophyceae, since stress-dependent chl breakdown has been shown to target primarily chl $b$ in plant chloroplasts (e.g. Ladygin \& Semenova 1993).

With the current knowledge on average periods of 20 to 30 min for complete vertical mixing cycles in the shallow water bodies and steep vertical gradients in irradiance availability, the kind of photosynthetic acclimation in the daily course and over large distances in the estuary could be assigned to the combined effects of high incident irradiance during clear sky periods and acclimation to severe nutrient limitation, which coexist against a potentially high background of oxidative agents due to extensive oxygen oversaturation in summer. Even in turbid estuaries, predominantly positive relationships of phytoplankton growth rate and light exposure (e.g. Alpine \& Cloern 1988) could turn to negative relationships under certain conditions. A possible interaction of macronutrients (phosphorus) and micronutrients (iron) in the regulation of phytoplankton development will be tested in future fertilisation experiments in summer with special respect to the irradiance acclimation response.

Although eutrophication often leads to a reduction of phytoplankton diversity in aquatic systems or diversity decreases with increasing biomass concentration and production (e.g. Duarte et al. 2006), the highly productive Darss-Zingst estuary provided maximum diversity $\left(H^{\prime}\right)$ (Fig. 6A) at most productive sites (Fig. 4), when calculations were based on 'functional individuals', i.e. all types of uni-species cell associations (colony, filament, coenobium) and unicellular species. With this definition, numerical values for $H^{\prime}$ differ from values that are based on biomass and cell number. Furthermore, any counting procedure of individuals could lead to divergent results if a numerical estimate of individuals is supported by time-saving approximations (e.g. average of individual numbers in multi-species aggregations, post-counting definition of individuals by average filament length units). This view of diversity pays more attention to the interactive biological unit, assuming that every association of cells and every free-living cell of a species represents an information unit (individual), which results from and coordinately interacts with the environment on relatively short time scales. Such individuals should reflect a current ecosystem framework more sensitively than e.g. biomass-based units, since biomass is a rather indirect proxy for the diversity of sensing and simultaneously self-regulating biological units. In addition, turnover diversity $\left(\beta_{\mathrm{S}}\right)$, number of dominant $16 \mathrm{~S}$ rDNA genotypes (Fig. 6B) as well as the positive correlation of $H^{\prime}$ and phytoplankton biomass concentration (Fig. 7) at least partially support the findings that phytoplankton diversity and species richness are higher in the more productive water bodies compared to the transition zone near the Baltic Sea. Generally, picocyanobacteria display the entire spectrum of salinity resistance (e.g. Fulda et al. 1999), but mapping of genotypes revealed ubiquitous distribution of moderately tolerant cyanobacteria and a dominating genotype in the group of picocyanobacteria (Geiß et al. 2004). Thus, a total inversion of the suggested relationship between $H^{\prime}$ and phytoplankton biomass by a hidden diversity of optically indistinguishable picocyanobacteria is less probable. Evaluation of a large number of Finnish lakes also indicated increasing species number with increasing biomass at least to biomass values of $5 \mathrm{mg}$ $\mathrm{l}^{-1}$ (Heinonen 1980). For the estuary, the relationship can only be discussed in respect to general hypotheses. An increase in species richness with increasing 
resources and primary production has been demonstrated in terrestrial ecosystems (e.g. Currie \& Paquin 1987). However, a general increase in spatial and temporal heterogeneities must be responsible for enhanced diversity at potentially more productive sites. The Immediate Disturbance Hypothesis (IDH) of Connell (1978), which suggests an optimum relationship between frequency of disturbance and coexistence, has been verified for experimental phytoplankton systems (e.g. Gaedeke \& Sommer 1986). Wilson (1994) discussed basic preconditions of the IDH theory (e.g. local differentiation of disturbance, minimum frequency, relationships to generation time). On the background of generation time (scale of days), different kinds of disturbance are of less importance for the Darss-Zingst estuary in prevailing clear-sky summer periods (e.g. river runoff, saltwater inflow, storm events). In fact, experimental tests on phytoplankton communities of tidally influenced lakes indicate that salinity pulses at intervals of a few days tend to promote phytoplankton diversity (Flöder \& Burns 2004). Taking into consideration the high DIN concentrations and the unexpectedly low impact of the gradient in $\mathrm{k}_{\mathrm{PAR}}$ on irradiance acclimation, the disturbance of the SRP supply might be a critical parameter. If IDH provides the appropriate model, optimum frequency of disturbances in SRP supply and maximum $H^{\prime}$ at Stn 3 (Fig. 1) suggests divergent mixing regimes in the estuarine basins, which has not been shown so far. A simply more intensive SRP release from the sediment at Stn 3, which maintains maximum $H^{\prime}$ due to stimulation of primary production, cannot be explained, since oxygen oversaturation and $\mathrm{pH}$ (Table 2) gave no indications, respectively, for a divergent oxygenation at the sediment surface. In this situation, we favour the hypothesis that competition between species for multiple resources and corresponding non-equilibrium dynamics may promote diversity (Huisman \& Weissing 2002) of phytoplankton at highly productive sites in the estuary, assuming a higher probability of such a multiple competition here in summer. This probability might be further enhanced due to a potentially complex framework of limitations (availability of phosphorus, iron, and PAR) and general stress (high irradiance, oxidative agents). A close linkage of the physiological response to some of these stressors by phytoplankton species might maintain diversity according to the hypothesis of positively correlated species co-tolerance (Vinebrooke et al. 2004). However, current experimental studies generally support positive relationships of productivity and diversity of aquatic microbes in heterotrophic communities (Jiang \& Morin 2004). In addition, a positive correlation of primary production and phytoplankton diversity has been observed for tidal cycles in an estuary. This led to the assumption that biovolume and species diversity could be major factors influencing photosynthesis (Jouenne et al. 2005). The study on phytoplankton diversity of the Darss-Zingst estuary was unusual because of the high spatial resolution of sampling sites in a short timeframe. The percentage of cyanobacterial biomass was about twice as much as in winter and spring (Schumann et al. 2005). The key processes that potentially mediate an increasing number of limiting resources and correspondingly increasing diversity in the more productive basins of the Darss-Zingst estuary in summer still need to be conclusively resolved. Furthermore, the impact of viruses on diversity is still unknown. An inverse relationship of productivity and diversity, as commonly expected, can thus far not be excluded for other seasons.

\section{CONCLUSIONS}

The relatively high spatial resolution of combined investigations in the summer season led to the discovery of unexpected features of the Darss-Zingst estuary, but this resulted in the loss of detail in the analyses. A maximum of phytoplankton diversity at low saline sites may be attributed to an internal control of phytoplankton development in the inner estuarine basins. This was supported by dissolved nutrients, since even high DIN concentrations did not follow the entire salinity gradient. Phosphorus and iron possibly interfere with each other in limiting total phytoplankton growth. Therefore, sediments that are very rich in both nutrients limit maximum consumption of these autochthonous nutrients in the pelagial. The inner basins may partially tend toward conditions that are found in brackish lakes with low water exchange. In this way, the positive correlation of biomass and phytoplankton diversity is partially caused by the restricted estuarine mixing gradient. Nevertheless, the mode of nutrient limitation does not necessarily change along the longitudinal expansion, since photosynthetic parameters that indicate high nutrient deprivation may be synchronised in the entire system. Not least, this may be attributed to the cyanobacterial dominance in summer. Other biological and chemical parameters clearly follow the mixing gradient and indicate the typical background of estuarine conditions. Even during the specific summer situation, regarding the estuary as a chain of autonomous or identical waters may only be appropriate when targeting selected features. These investigations were at the lower limit for reliably detecting longitudinal patterns. Especially for seasons of maximum variability, the need for truly synoptic studies with a reasonable number of sampling sites in order to eliminate variability between sites in a diel 
course persists. In this context, the adjustment of sophisticated biological methods to the frequency of rapid changes in situ will be a crucial component in resolving causal mechanisms of phytoplankton dynamics on short-term scales.

Acknowledgements. This study was supported by grants from the Deutsche Forschungsgemeinschaft (DFG) and the Deutsche Bundesstiftung Umwelt (DBU). We thank the crew of the Biological Station Zingst (University of Rostock) for kind support of the field work. The detailed and helpful suggestions of an anonymous reviewer are gratefully acknowledged.

\section{LITERATURE CITED}

Alpine AE, Cloern JE (1988) Phytoplankton growth rates in a light-limited environment, San Francisco Bay. Mar Ecol Prog Ser 44:167-173

Anagnostidis K, Komárek J (1988) Modern approach to the classification system of cyanophytes. 3 - Oscillatoriales. Arch Hydrobiol Suppl 80 (Algol Stud 50-53):327-472

Behrendt H, Huber P, Kornmilch M, Opitz D and others (1999) Nährstoffbilanzierung der Flußgebiete Deutschlands. Texte des Umweltbundesamtes 75/99, Berlin

$>$ Boynton WR, Kemp WM (1985) Nutrient regeneration and oxygen consumption by sediments along an estuarine salinity gradient. Mar Ecol Prog Ser 23:45-55

Brand LE (1991) Minimum iron requirements of marine phytoplankton and the implications for the biogeochemical control of new production. Limnol Oceanogr 36:1756-1771

> Campbell D, Öquist G (1996) Predicting light acclimation in cyanobacteria from nonphotochemical quenching of photosystem II fluorescence, which reflects state transitions in these organisms. Plant Physiol 111:1293-1298

Campbell D, Hurry V, Clarke AK, Gustafsson P, Öquist G (1998) Chlorophyll fluorescence analysis of cyanobacterial photosynthesis and acclimation. Microbiol Mol Biol Rev 62:667-683

> Clavero V, Izquierdo JJ, Fernández JA, Niell FX (2000) Seasonal fluxes of phosphate and ammonium across the sediment-water interface in a shallow small estuary (Palmones River, southern Spain). Mar Ecol Prog Ser 198:51-60

> Connell JH (1978) Diversity in tropical rain forests and coral reefs. Science 199:1302-1310

Currie DJ, Paquin V (1987) Large-scale biogeographical patterns of animal and plant species richness in trees. Nature 329:326-327

Duarte P, Macedo MF, da Fonseca LC (2006) The relationship between phytoplankton diversity and community function in a coastal lagoon. Hydrobiologia 555:3-18

Eyre B, Twigg C (1997) Nutrient behaviour during post-flood recovery of the Richmond River Estuary Northern NSW, Australia. Estuar Coast Shelf Sci 44:311-326

Flöder S, Burns CW (2004) Phytoplankton diversity of shallow tidal lakes: influence of periodic salinity changes on diversity and species number of a natural assemblage. J Phycol 40:54-61

Forsgren G, Jansson M, Nilsson P (1996) Aggregation and sedimentation of iron, phosphorus and organic carbon in experimental mixtures of freshwater and estuarine water. Estuar Coast Shelf Sci 43:259-268

Forster RM, Schubert H (2001) The effects of ultraviolet radiation on the planktonic community of a shallow, eutrophic estuary: results of mesocosm experiments. Helgol Mar Res 55:23-34

Franks PJS, Marra J (1994) A simple new application for phytoplankton photoresponse and an application in a wind-driven model. Mar Ecol Prog Ser 111:143-153

Fulda S, Huckauf J, Schoor A, Hagemann M (1999) Analysis of stress responses in the cyanobacterial strains Synechococcus sp. PCC 7942, Synechocystis sp. PCC 6803, and Synechococcus sp. PCC 7418: Osmolyte accumulation and stress protein synthesis. J Plant Physiol 154:240-249

- Gaedeke A, Sommer U (1986) The influence of the frequency of periodic disturbances on the maintenance of phytoplankton diversity. Oecologia 71:25-28

Gasiūnaitė ZR, Cardoso AC, Heiskanen AS, Henriksen P and others (2005) Seasonality of coastal phytoplankton in the Baltic Sea: influence of salinity and eutrophication. Estuar Coast Shelf Sci 65:239-252

Geiß U, Vinnemeier J, Kunert A, Lindner I and others (2001a) Detection of the isiA gene across cyanobacterial strains: potential for probing iron deficiency. Appl Environ Microbiol 67:5247-5253

Geiß U, Vinnemeier J, Schoor A, Hagemann M (2001b) The iron-regulated isiA gene of Fischerella muscicola strain PCC 73103 is linked to a likewise regulated gene encoding a Pcb-like chlorophyll-binding protein. FEMS Microbiol Lett 197:123-129

Geiß U, Bergmann I, Blank M, Schumann R, Hagemann M, Schoor A (2003) Detection of Prochlorothrix in brackish waters by specific amplification of $p c b$ genes. Appl Environ Microbiol 69:6243-6249

Geiß U, Selig U, Schumann R, Steinbruch R, Bastrop R, Hagemann M, Schoor A (2004) Investigations on cyanobacterial diversity in a shallow estuary (Southern Baltic Sea) including genes relevant to salinity resistance and iron starvation acclimation. Environ Microbiol 6:377-387

Genty B, Briantais JM, Baker NR (1989) The relationship between the quantum yield of photosynthetic electron transport and quenching of chlorophyll fluorescence. Biochim Biophys Acta 990:87-92

Gerloff GC, Skoog FE (1957) Availability of iron and manganese in Southern Wisconsin lakes for the growth of Microcystis aeruginosa. Ecology 38:551-556

Görs S, Rentsch D, Schiewer U, Karsten U, Schumann R (2007) Dissolved organic matter along the eutrophication gradient of the Darß-Zingst Bodden Chain, Southern Baltic Sea: I. Chemical characterisation and composition. Mar Chem 104:125-142

$>$ Gray JS (2000) The measurement of marine species diversity, with an application to the benthic fauna of the Norwegian continental shelf. J Exp Mar Biol Ecol 250:23-49

Heinonen P (1980) Quantity and composition of phytoplankton in Finnish inland waters. Publ Water Res Inst 37, National Board of Waters, Vesihallitus

> Hopkinson CS, Giblin AE, Tucker J, Garritt RH (1999) Benthic metabolism and nutrient cycling along an estuarine salinity gradient. Estuaries 22:863-881

> Huisman J, Weissing FJ (2002) Oscillations and chaos generated by competition for interactively essential resources. Ecol Res 17:175-181

Jiang L, Morin PJ (2004) Productivity gradients cause positive diversity - invasibility relationships in microbial communities. Ecol Lett 7:1047-1057

Jouenne F, Lefebvre S, Veron B, Lagadeuc Y (2005) Biological and physicochemical factors controlling short-term variability in phytoplankton primary production and photosynthetic parameters in a macrotidal ecosystem (eastern English Channel). Estuar Coast Shelf Sci 65:421-439 
Kromkamp JC, Forster RM (2003) The use of variable fluorescence measurements in aquatic ecosystems: differences between multiple and single turnover measuring protocols and suggested terminology. Eur J Phycol 38:103-112

Ladygin VG, Semenova GA (1993) The influence of irondeficiency on the composition of chlorophyll-protein complexes and the ultrastructure of pea chloroplasts. Russ J Plant Physiol 40:723-731

Lemaire E, Abril G, De Wit R, Etcheber H (2002) Distribution of phytoplankton pigments in nine European estuaries and implications for an estuarine typology. Biogeochemistry 59:5-23

Lizon F, Lagadeuc Y, Brunet C, Aelbrecht D, Bentley D (1995) Primary production and photoadaptation of phytoplankton in relation with tidal mixing in coastal waters. J Plankton Res 17:1039-1055

MacIntyre HL, Cullen JJ (1996) Primary production by suspended and benthic microalgae in a turbid estuary: timescales of variability in San Antonio Bay, Texas. Mar Ecol Prog Ser 145:245-268

- Malcolme-Lawes DJ, Koon HW (1990) Determination of orthophosphate in water and soil using a flow analyzer. Analyst (Lond) 115:65-67

Nausch G, Schlungbaum G (1977) Sediment-chemical studies on the coastal waters of the GDR. 3. Phosphorus-iron ratios in soil contact water, in slurry and in sediments of the Darss-Zingster Bodden chain. Acta Hydrochim Hydrobiol 5:455-463

Nausch G, Schlungbaum G (1984) Die Sedimente der DarßZingster Boddengewässer - eine zusammenfassende und vergleichende Übersicht. Wiss Z Univ Rostock 33:59-63

$>$ Neidhardt J, Benemann JR, Zhang LP, Melis A (1998) Photosystem II repair and chloroplast recovery from irradiance stress: relationship between chronic photoinhibition, light-harvesting chlorophyll antenna size and photosynthetic productivity in Dunaliella salina (green algae). Photosynth Res 56:175-184

Öquist G (1974) Iron-deficiency in the blue-green alga Anacystis nidulans: fluorescence and absorption spectra recorded at $77 \mathrm{~K}$. Physiol Plant 31:55-58

Pankow H (1990) Ostsee-Algenflora, 1st edn. Fischer, Jena

Pilkaitytë R, Schoor A, Schubert H (2004) Response of phytoplankton communities to salinity changes - a mesocosm approach. Hydrobiologia 513:27-38

Pitkänen H, Tamminen T (1995) Nitrogen and phosphorus as production limiting factors in the estuarine waters of the eastern Gulf of Finland. Mar Ecol Prog Ser 129:283-294

Pullin MJ, Cabaniss SE (2003) The effects of $\mathrm{pH}$, ionic strength, and iron-fulvic acid interactions on the kinetics of non-photochemical iron transformations. II. The kinetics of thermal reduction. Geochim Cosmochim Acta 67: 4079-4089

Rohde KH, Nehring D (1979) Ausgewählte Methoden zur Bestimmung von Inhaltsstoffen im Meer- und Brackwasser. Geodät Geophys Veröff, Berlin, R IV 27:31-37

Sagert S, Schubert H (2000) Acclimation of Palmaria palmata (Rhodophyta) to light intensity: comparison between artificial and natural light fields. J Phycol 36:1119-1128

Schiewer U (1997) 30 years' eutrophication in shallow brackish waters-lessons to be learned. Hydrobiologia 363: 73-79

Schlungbaum G, Nausch G (1988) Nutrient turnover at the sediment/water interface in shallow eutrophic coastal waters. Kiel Meeresforsch (Sonderh) 6:184-190

Schlungbaum G, Baudler H, Nausch G (1994) The DarssZingst Bodden chain - a typical shallow water estuary at the southern Baltic coast. Rostock Meeresbiol Beitr 2:5-26
Schlüter L, Riemann B, Søndergaard M (1997) Nutrient limitation in relation to phytoplankton carotenoid/chlorophyll a ratios in freshwater mesocosms. J Plankton Res 19: 891-906

Schubert H, Forster RM (1997) Sources of variability in the factors used for modelling primary productivity in eutrophic waters. Hydrobiologia 349:75-85

Schubert H, Forster RM, Sagert S (1995) In situ measurement of state transition in cyanobacterial blooms-kinetics and extent of the state change in relation to underwater light and vertical mixing. Mar Ecol Prog Ser 128:99-108

Schubert H, Forster RM, Schoor A, Ockenfeld K (1997) Horizontal and vertical chlorophyll distribution in the Bodstedter Bodden. Rostock Meeresbiol Beitr 5:69-83

Schubert H, Sagert S, Forster RM (2001) Evaluation of the different levels of variability in the underwater light field of a shallow estuary. Helgol Mar Res 55:12-22

Schubert H, Schlüter L, Feuerpfeil P (2003) The ecophysiological consequences of the underwater light climate in a shallow Baltic estuary. ICES Coop Res Rep 257:29-37

Schumann R, Rentsch D, Görs S, Schiewer U (2001) Seston particles along a eutrophication gradient in coastal waters of the Southern Baltic Sea: significance of detritus and transparent mucoid material. Mar Ecol Prog Ser 218:17-31

Schumann R, Hammer A, Görs S, Schubert H (2005) Winter and spring phytoplankton composition and production in a shallow eutrophic Baltic lagoon. Estuar Coast Shelf Sci 62:169-181

Selig U, Berghoff S, Schlungbaum G, Schubert H (2005) Variation of phosphate in sediments along an estuarine salinity gradient of the Baltic Sea. In: Serrano L, Golterman HL (eds) Phosphates in sediments. Proc 4th Int Symp, Bachhuys Publ, Leiden, p 33-42

Selig U, Baudler H, Krech M, Nausch G (2006) Nutrient accumulation and nutrient retention in coastal waters-30 years investigation in the Darss-Zingst Bodden chain. Acta Hydrochim Hydrobiol 34:9-19

Stookey LL (1970) Ferrozine-a new spectrophotometric reagent for iron. Anal Chem 42:779-81

Urabe J (1993) Seston stoichiometry and nutrient deficiency in a shallow eutrophic pond. Arch Hydrobiol 126:417-428

Verardo DJ, Froelich PN, McIntyre A (1990) Determination of organic carbon and nitrogen in marine sediments using the Carlo Erba NA-1500 Analyser. Deep-Sea Res 37: 157-165

Vinebrooke RD, Cottingham KL, Norberg J, Scheffer M, Dodson SI, Maberly SC, Sommer U (2004) Impacts of multiple stressors on biodiversity and ecosystem functioning: the role of species co-tolerance. Oikos 104:451-457

- Walsby AE (1997) Numerical integration of phytoplankton photosynthesis through time and depth in a water column. New Phytol 136:189-209

Wasmund N (1994) Phytoplankton periodicity in a eutrophic coastal water of the Baltic Sea. Int Rev Gesamt Hydrobiol 79:259-285

Wen LS, Santschi P, Gill G, Paternostro C (1999) Estuarine trace metal distributions in Galveston Bay: importance of colloidal forms in the speciation of the dissolved phase. Mar Chem 63:185-212

Wilson JB (1994) The 'Intermediate Disturbance Hypothesis' of species coexistence is based on patch dynamics. NZ J Ecol 18:176-181

Zwolsman JJG, van Eck BTM, van der Weijden CH (1997) Geochemistry of dissolved trace metals (cadmium, copper, zinc) in the Scheldt estuary, southwestern Netherlands: Impact of seasonal variability. Geochim Cosmochim Acta 61:1635-1652 